\title{
THE IMPORTANCE OF ENFORCING THE FUNDAMENTAL PRINCIPLES OF INTERNATIONAL LAW DURING THE NEGOTIATION PROCESS Dan GUNĂ
}

\author{
"Valahia" University, Târgovişte, Romania \\ gunadan@yahoo.com
}

\begin{abstract}
Diplomatic negotiations represent the most frequently regulated and used method when it comes to states settling their international conflicts. The negotiation process can be influenced by many factors, such as: the characteristics of the conflict, the power balance, the relation between the parties in conflict. From the perspective of international law, a significant importance for the success of negotiations is held by the observance of some principles such as: sovereign equality of the parties, the absence of force or threat to use the force, good faith, lack of interference in internal affairs, abstention from committing any act capable to worsen the conflict. For a solid lengthy settlement of a conflict, no solution can be imposed by using the force or threatening to use it and, hence, transgressing the essential attribute of states - sovereignty. States must show a good faith attitude during negotiations and use this diplomatic method with the real intent of settling the conflict and not for other strategic reasons, like getting extra time or creating a good faith appearance in front of the public opinion as they were looking for a solution.
\end{abstract}

\section{Keywords: diplomatic negotiations, principles of international law}

\section{Peaceful solving of disputes and the principles of international law}

The principles of international law are norms with universal enforcement, with a maximum level of generality and with an imperative character, which provide expression forms and protect a fundamental value throughout the relations between international law subjects [1].

Only considered on the whole and in their interdependence, all these features can constitute a necessary criterion for distinguishing fundamental principles from other principles and legal norms of the relations between the states [2].

Regarding the diplomatic settlement of conflicts, it must be noticed that, when it comes to the peaceful settlement of an international dispute, all the principles in question or a great part of them are found as enforceable rules many times. They constitute a whole, being strongly connected, both in terms of their content and enforcement process. Thus, some elements of one principle are taken over by another one, from another perspective; they are mutually completed and explained; none of them can be enforced by ignoring the content of the others [3]. This interaction can also be seen from the way these principles are regulated by some international documents, particularly the resolutions of the U.N. General Assembly.

2. Principles applicable to diplomatic negotiations

There are no imperative rules clearly regulated when it comes to carrying out the negotiations for the settlement of conflicts. Nonetheless, the observance of international public law norms during the negotiation 
process is a requirement for this method to be efficient. Some concrete references to principles such as the peaceful settlement, cooperation or good faith, which must constitute guidelines for the resolution of conflicts, can be found in international conventions: the 1982 Convention on the Law of the Sea (article 300), the 1997 Convention (article 17.2), Annex 2 of the Marrakesh Agreement (article 4).

Several resolutions of the UN General Assembly contain references to the norms which must be enforced to international negotiations. Thus, Resolution 2625 from 1970 establishes the principle of fast settlement, ever since the conflict emerges, but also its just equitable settlement. At the same time, is underlined the importance of observing the principle of sovereign equality between the states and the principle of the freedom to choose the methods during the process for the conflicts settlement. The Manila Declaration from 1982 underlines at point 5 that the settlement of disputes will be done on the basis of sovereign equality between the states and the freedom to choose the means, in accordance to the principles of justice and international law.

The Resolution 53/101 (20.01.1999) adopted by the General Assembly is dedicated to the principles and guidelines for international negotiations. The preamble of this resolution states that negotiations must be guided by the principles and relevant laws of international law. Among the principles enforceable to negotiations, the resolution reminds at point 1 :

- sovereign equality of all States, notwithstanding differences of a political or economic nature;

- $\quad$ states have the duty not to intervene in matters within the domestic jurisdiction of any state;

- states have the duty to fulfil in good faith their obligations under international law;

- states must refrain from the threat or use of force;
- $\quad$ states have the duty to cooperate with one another, irrespective of their political or economic system;

- $\quad$ states must settle their disputes so that international peace, security and justice are not endangered.

Point 2 of the Resolution indicates the guidelines which states should apply during negations:

- negotiations should be conducted in good faith;

- states should take due account of engaging in negotiations also some other states whose interests are affected by the matter in question;

- the purpose and object of all negotiations must be fully compatible with the principles and norms of international law

- states should endeavour to maintain a constructive atmosphere during negotiations and to refrain from any action which could adversely affect the success of negotiations;

- states should endeavour to find mutually acceptable solutions, particularly in the event of an impasse in negotiations.

\subsection{The principle of peaceful settlement and that of refraining from the threat or use of force.}

In order to underline the connection between these principles and the negotiations process, it would be relevant to mention the observations of the Romanian professor Mircea Maliţa: "the organization of negotiations itself represents the assertion of two fundamental principles: abstention of states, in the relations between them, from the threat or use of force and the principle of peaceful settlement of the conflicts between states. The negotiations act signifies to simultaneously acknowledge the renunciation to force and the acceptance of a peaceful method to settle disputes" [4]. It could be also added the fact that, in order to represent a way of renunciation to force, the initiation of negotiations must be made in good faith, with the intention to resolve 
the conflict. Sometimes, the performance of negotiations can be justified by other aspects, such as: gaining more time to recover or creating a cooperation appearance. This technique was applied by Iran between 2002-2005, during its dispute on nuclear weapons with the U.S.A. Thus, Iran entered negotiations on international inspections with the European allies of the U.S.A., letting the appearance that it wanted to cooperate for the settlement of the issue on a diplomatic manner. In these conditions, the military intervention upheld by the U.S.A. would have appeared as not justified. By means of these techniques, Iran also gained the necessary time for constructing nuclear weapons.

The enforcement of the two principles in question during the negotiation process presupposes the exclusion of any form of using or threating to use force against state representatives or the state itself. The area of constraint deeds which are generally forbidden by international law, but also during the negotiation process, is not limited to the use of armed force, but also to political and economic pressures. During international negotiations, many such pressures forms are used. The Cuban Missile Crisis during the Cold War is an example of negotiations held under the pressure of using nuclear weapons. Nowadays, countries such as Iran and North Korea noticeably use the threat to use nuclear weapons as a negotiation method.

On the basis of these principles, states are bound, even if negotiations fail, not to resort to the use of force and to continue their efforts to find a peaceful solution. Resolution No. 2625 from 1970 clearly demands to states not to abandon the identification of a solution when a method fails and to continuously endeavour during the conflict to resolve it.

Many conventions provide that, if negotiations fail, but also if parties do not reach an agreement regarding the appeal to an international court (the appeal compromise being also a result of negotiations), the consultations for the peaceful settlement of the conflict must be continued.

Applications of the rules mentioned above can be found in conventions such as: the Convention on the Law of the Sea from 1982 (article 283.2), which provides that: "parties shall proceed immediately to an exchange of opinions, any time a procedure for the settlement of such conflict was concluded, but the conflict was not resolved or a settlement has been found but the circumstances impose consultations on the ways to enforce it".

Similar provisions can also be found in the Convention for the Conservation of Southern Bluefin Tuna signed in 1993 by Australia, Japan, New Zeeland (article 16.2) and the Noumea Convention from 1986 for the Protection of the Natural Resources and Environment of the South Pacific Region (article 26.2).

\subsection{The principle of sovereign equality}

The observance of this principle during contemporary negotiations is really hard to accomplish, under the circumstances in which, after the end of the Cold War, many bloody civil conflicts have broken and the international community had to intervene many times by using force, out of humanitarian reasons, although force is seen as a last resort.[5] The negotiations of the Dayton Accords (1995), by means of which the state Bosnia-Herzegovina was created, but also those between the Serbs and Albanians for the independence of the Kosovo province, are only some examples in which the respect of sovereignty was no longer a principle of this settlement method. There are also examples in which national sovereignty was observed and a solution acceptable for both parties was reached, but with more difficulty. The negotiations for the comeback of Hong Kong to China out the domination of Great Britain demonstrated that the national sovereignty is not an immutable concept, while the identification of a solution commonly agreed, by means of talks, also imposes 
limitations of sovereignty sometimes.

Thus, after two years of difficult negotiations between Margaret Thatcher the British prime-minister - and the Chinese leaders, an Agreement was signed, by means of which Great Britain was giving Hong Kong back to China while the latter took upon the commitment to restrict some of the attributes of its sovereignty, so that the special administrative region of Hong Kong benefitted from an expanded autonomy. According to the principle, "a country two systems", Hong Kong benefits until 2047 from a capitalist and executive system and from its own Parliament.

In some international conflicts, the exaggeration of the respect for national sovereignty, irrespective of the nature of the situation, is an obstacle both for the initiation of negotiations and for the settlement of the dispute by means of the latter. Such examples can be found in the case of divided resources, which do not respect political borders of states. International water courses do not respect the artificial division made by the states and a good management of them must start from the observance of the principle of collaboration and good faith. By means of a more open approach towards mutually advantageous concessions, states can strengthen their national sovereignty and prevent the deepening of the disputes between them. The reference to the absolute sovereignty thesis, having negative consequences upon the negotiations between the states, can also be found in the attitude of Ukraine in the dispute with Romania regarding the Bystroye Canal.

One of the great disadvantages of the negotiation method is that it allows the use of the differences of power between the states. International reality has proven many times that the principle of the states' rights equality, which is a natural consequence of sovereignty, is transgressed during international negotiations. For instance, during the Cold War, there was the obvious tendency of the two superpowers, U.S.A. and U.S.S.R., to monopolize the negotiations for some litigious issues, whose resolution was also desired by other states too. Nonetheless, sometimes even small states managed to get involved in the negotiations of some conflicts in which were also involved the great powers, directly or indirectly. Such an example is also the contribution of Romania to the negotiations between the U.S.A. and Vietnam, which put an end to a bloody conflict. Thus, without officially taking upon a mediation action, it managed at least to determine parties to listen to one another mutually [6].

The references to the equality of states' rights during negotiations can also be found in the practice of the International Court of Justice; thus, in the Advisory Opinion on the Status of South-West Africa from 1950, the court was pointing out that all states must be entitled to an opinion when exerting their rights, but also the accomplishment of their obligations. There must be neither discrimination nor preferential treatment, all states being capable to use all the range of their prerogatives derived from sovereignty and independence.

Sometimes states, in order not to prevent the course of negotiations, prefer to conclude some partial provisory agreements on a disputed zone, from the perspective of sovereignty. In order to maintain their sovereignty claims upon the sea areas in conflict, states resort to common agreements of use, by means of which the negotiations for establishing the sea borders can take place at the same time with the exploitation of the sea ground resources on the common benefit.

During international negotiations, states must abide by their duty of not meddling in the internal affairs of another state, a duty meant to protect national sovereignty. Nowadays, the intervention in the internal affairs takes place particularly when it comes to the attempts to settle civil wars. In the case of many internal conflicts, the 
international community has intervened in the negotiations between factions in the form of mediation and good offices. On this occasion, the principle of the noninterference can be easily transgressed, if the mediator is interested in upholding one of the parties or maintaining the conflict. For instance, during the rebellion in the South of Sudan, Ethiopia got involved as a mediator. After the fall of the Addis Ababa Agreement, in 1972, the insurgence moved on the territory of Ethiopia, which became rather a part of the conflict than a mediator. The relations between the Sudan People's Liberation Army and Ethiopia became very close. The efforts of the Sudan Government of reopening the negotiations encountered the refuse of Ethiopia, interested in maintaining the conflict.

\subsection{The principle of cooperation}

This principle is intrinsic to the international negotiation, as the latter represents a consensual activity and it cannot take place without the agreement of the parties involved. It must be noticed that there are also conventions demanding the compulsory use of negotiations. Yet, even in these cases, if one of the parties does not cooperate to the negotiation process, the latter will fail, and the party in question will be held accountable for not meeting a requirement established by agreement, the conflict remaining not resolved.

The observance of this principle is essential for resolving the conflicts regarding the exploitation of resources divided between more states (like cross-border water courses), but also environmental protection. When it comes to disputes focusing on areas not subject to sovereignty, like the free sea or the extra-atmospheric space, the cooperation between the states is a demand without which the disputes in question are quite hard to be resolved.

\subsection{The good faith principle}

Good faith in negotiations means to initiate them with the firm intention to reach an equitable solution, parties making real efforts for this purpose. The purpose of negotiations must be the settlement of the conflict and not its postponement or creating a false impression of cooperative attitude. Good faith is shown during negotiations also by means of an attitude open towards compromise and the renunciation to some claims.

Several resolutions of the General Assembly make references to the observance of the good faith duty for the resolution of disputes. Thus, Resolution No. 2625 from 1970 refers to the good faith principle ever since its preamble, where it is underlined its major importance for maintaining peace and international security, but also for accomplishing in good faith the other objectives of the organization and the duties taken upon on the basis of the Paper. Moreover, the resolution reminds as codified principle the accomplishment in good faith of the obligations assumed according to the norms of the international law. The Manila Declaration from 1982 emphasizes good faith in the action of states of preventing disputes, at point 1 . At point 5 of the same document, states are demanded to seek to settle their conflicts in a rapid equitable manner and in the spirit of good faith. Resolution No. 43/51 from 1988 provides that states must prevent the emergence or aggravation of disputes within international relations, particularly by meeting their duties in good faith (article 1(1)).

In some international conventions, good faith is clearly indicated as a demand for carrying out negotiations. For instance, article 4.3. of Annex 2 of the Marrakech Agreement stipulates: "if an advisory application is made on the basis of an authorized agreement, the Member to whom the application was addressed will answer to it, if there is no common agreement, within the 10 days following the date when the application was received and will go through advisory procedure in good faith, at latest 30 days after receiving the application, for the purposes of reaching a mutually satisfactory solution. The 1997 
Convention stipulates at article 17.2: "negotiations and consultations will take place on the basis of the principle according to which each state must take into account the rights and legitimate interests of the other state in good faith and in a reasonable manner".

The observance of the good faith principle for resolving disputes has also been underlined throughout the legal practice of the ICJ, in case files like: the North Sea Continental Shelf, Gabcikovo-Nagymaros, the air incident between Pakistan and India in 1999.

One of the consequences of this principle is also that the parties involved in the dispute must refrain from any act which could worsen the conflict, during the negotiation phase. This duty is also underlined by the Resolution No. 2625 from 1970, which asserts that the states which are part of a conflict, but also other states, must refrain from any act which could worsen the dispute or endanger international peace and security. Similar provisions are also contained by point 8 of the Manila Declaration.

\section{Conclusions}

Finally, the importance of respecting the principles of international law in the process of peacefully solving a dispute through negotiations cannot be underestimated. This aspect is underlined by numerous international documents as well as diplomatic practice. Sticking to these principles signals the intention of solving a certain dispute in a durable way. Searching for solutions in solving a dispute must be done swiftly, without employing force and in good will during the entire process.

All sides involved are free to choose their means and must cooperate on a basis of equality and mutual gain in both direct negotiations and in third party mediation. In this case dispute solving should be carried out objectively and in full respect of national sovereignty.

\section{References}

[1] Dumitra Popescu, Adrian Năstase (coordinators), Sistemul principiilor dreptului internațional, Academiei, Publ. House, Bucharest, 1986, p.20.

[2] Gheorghe Moca, Mircea Duțu, Drept internaţional public, proceedings I, Universul juridic Publ. House, Bucharest, 2008, p. 161.

[3] Ion Diaconu, Tratat de drept internaţional public, Lumina Lex Publ. House, Bucharest, 2002, vol.1, p.329.

[4] Maliţa Mircea, Teoria şi practica negocierilor, Ed. Politică, Bucharest, p.292.

[5] D. Barbu, Răspunderea persoanei fizice în dreptul internațional penal,Ed. Lumen, Iasi,2015, pp.55-88.

[6] Dr. Lucian D. Petrescu, Rolul diplomaţiei române în negocierile pentru încetarea conflictului din Vietnam. Sprijinul acordat de România în obţinerea victoriei finale în Pagini din diplomaţia României, coordinators I.M. Anghel, Lucian Petrescu, Valeriu Tudor, Junimea Publ. House, Iaşi, 2009, p.226. 